\title{
An Analysis of Equalizing Capacity of State Transfers for Local Government Activities in Bulgaria ${ }^{1}$
}

\section{Presiana Nenkova*}

\section{Abstract}

The aim of this paper is to examine the fiscal disparities among local governments in Bulgaria and to show the capabilities of the existing intergovernmental transfer system to reduce them. Fiscal equalization policy in Bulgaria is performed through a general equalization transfer for local activities the distribution of which is based on local government tax revenue, as well as on service delivery costs. We measured the extent of equalization in three years - 2007, 2011 and 2017, during which the equalization transfer formula underwent considerable changes. For 265 municipalities we found out that, although the applied equalization mechanisms reduced the inequality in municipal own-source revenue the remaining fiscal disparities among local governments were still considerable. Our research also suggests that disparity-reducing strength of the general equalization transfer remained almost unchanged during the period under review with its equalizing potential hampered to a great extent by the inclusion of additional compensatory elements in the distribution formula.
Key words: decentralization, fiscal disparities, transfers, equalization, local governments, Bulgaria.

JEL: H71, H73, H77.

\section{Introduction}

The arguments in favour of fiscal decentralisation typically highlight the expected benefits of the process - greater efficiency, transparency and accountability of public spending (Tiebout, 1956; Oates,1972). These benefits notwithstanding, decentralisation may give rise to certain specific problems, notably horizontal imbalances. Some local governments have less own-income resources or experience higher public service delivery costs than others. As a result, there are variations in the ability of local governments to maintain a given level of public service delivery, which in turn leads to different treatment of otherwise equal people depending on their place of living. (Shah, 2007). Moreover, in presence of a fiscally induced migration, fiscal disparities among local governments could also give rise to inefficiency problems. As an inevitable part of each public sector decentralisation fiscal equalization systems are charged with the responsibility to 'eliminate differences in the net benefit that the public sector provides to otherwise-identical households residing in

\footnotetext{
The paper has been accepted for publication on $18^{\text {th }}$ of June 2019 .

University of National and World Economy, Department of Finance.
} 


\section{Articles}

different regions, so-called net fiscal benefits' (Boadway, 2004, p. 215).

The decentralisation of public finance in Bulgaria commenced in 2003 with a series of interventions aiming to clearly define municipal responsibilities and the sources of their financing, enhance financial independence of local governments, achieve greater transparency and ensure objectivity in the determination and allocation of transfers from the central government. Fifteen years after the onset of the reform, municipal budgets remain heavily reliant on transfers from the central government - the share of income from transfers currently exceeding $60 \%$ of total municipal revenue. And while the share of municipal spending in consolidated public spending is only $17 \%$ (in 2017), the own revenue of local authorities accounts for only $6.6 \%$ of consolidated public revenue. In addition to the lack of correspondence between the decentralisation of spending responsibilities and decentralization of revenue sources in the public sector of Bulgaria, there are also significant disparities among municipalities in terms of their financial capacity. For example, the indicator of own municipal revenue to total municipal revenue varies between $10 \%$ up to $85 \%$ (in 2017) against the national average of $38.9 \%$. Likewise, if own revenue from local taxes in the largest municipalities accounts for $25 \%$ of their total budget revenue, in smaller municipalities this figure is $15 \%$, and only $5 \%$ in the smallest agglomerations.

With this study we attempt to fill the knowledge gap about the effectiveness of the equalization system applied in Bulgaria in an effort to alleviate fiscal disparities between local governments. The State transfer system with its three components could be regarded as one of the pillars of the process of fiscal decentralization in Bulgaria. The general equalization transfer for local activities constitutes the only form of
An Analysis of Equalizing Capacity of State Transfers

for Local Government Activities in Bulgaria

intergovernmental fiscal relations in Bulgaria aimed at reducing fiscal inequality at local level. Easing the burden of delivering public services of a standard quality through the general equalizing grant has been envisaged in the Public Finance Act and the Strategies on Decentralisation.

It should be noted that Bulgaria presents an interesting case study on account of the large number of small territorial units approximately a quarter of all municipalities in the country have a population of less than 6000 people, which is the statutory minimum for creating a new municipality. This fact, along with the increasing concentration of the economic base in a handful of municipalities, is only one prerequisite for the existing considerable fiscal disparities at local level in Bulgaria. About 86 percent of the country's production, 80 percent of the total investment implemented, and three quarters of the economically active population are concentrated within 20 economic centers that amount to one third of the Bulgarian territory (IME, 2018). On the other hand, since the final effect of an equalization transfer on local fiscal disparities depends not only on the distribution formula but also on its relative importance in the municipal budgets, it should be mentioned that intergovernmental transfers in Bulgaria have a dominant role in municipal budgets as regards own revenue. Furthermore, to the extent that the last major steps to decentralising public finance in Bulgaria were taken in 2007 by granting tax autonomy to local governments with regard to local tax rates, one of the possibilities to rethink and reformulate decentralisation policy is to address fiscal imbalances.

This paper is organised as follows: Section 2 contains a review of relevant literature; Section 3 sets out a brief profile of municipal revenue in Bulgaria; Section 4 deals with the design of the equalization formula in Bulgaria 


\section{Articles}

and its changes over the years; Section 5 examines fiscal disparities among local governments before and after equalization as well as the disparity-reducing strength of the general equalization transfer; Section 6 contains a summary of the results.

\section{Literature Review and methodology used}

The extensive list of surveys dealing with fiscal equalization in particular countries as well as the growing number of comparative studies present strong evidence of a shift in academic interest to the issues at hand. Among many other we can mention few of them - the study of fiscal equalization in Austria (Schneider, 2002), the analysis of fiscal equalization system effectiveness in Croatia (Primorac, 2014; 2015), the evaluation of municipal transfer system in Nicaragua (Martinez-Vazquez and Sepulveda, 2008), the examination of fiscal equalization outcomes in Russia (Martinez-Vazques and Timofeev, 2006) as well as in Latin America and the Caribbean (Muñoz, Radics and Bone, 2016). An evaluation of the extent to which applied equalization mechanisms reduce fiscal disparities at sub-national level within OECD countries could be found in Blöchliger and Charbit (2008) and in OECD (2014), for Germany, Australia, Canada, Spain and Switzerland in Hierro, Atienza and Patiño (2007), for countries in East Asia in Hofman and Cordeira Guerra (2005). Empirical studies focus primarily on intermediate or regional levels of government and much less frequently on studying the imbalances and effects of equalization schemes aimed at reducing financial disparities at local level.

Empirical research relies on different instruments to measure fiscal disparities among sub-national governments and to assess the equalizing strength of intergovernmental transfers. A description and explanation of various measures of fiscal inequality could be found in Bird and Tarasov (2004), Shankar and Shah (2003), Portnov and Felsenstein (2010) and Kowalik (2015), all of them used in empirical studies. Primorac (2015) uses weighted Gini coefficients before and after application of different equalization instruments to analyze the effectiveness of Croatian fiscal equalization system. Yet again Blöchliger and Charbit (2008) rely on Gini coefficients and in addition on coefficients of variation to examine the effect of equalization in 14 OECD countries. In their study Martinez-Vazquez and Timofeev (2006) offer another approach to present the effect of intergovernmental reforms in Russia in 2001 - Lorenz curves for own-sources local revenue and assigned revenue and coefficient of variation as well as square coefficients of variation and mean log deviation in order to measure the contribution of each revenue source decomposing it into within-region and between regions components making for the inequality. Muñoz, Radics and Bone (2016) calculates Gini coefficients, the minimum to maximum ratio and coefficients of variation in their analysis of the equalization systems applied in ten Latin America countries. They also measure losses produced by re-ranking of intermediate levels of governments after the equalization. Kowalik (2015) measures horizontal fiscal imbalances in Germany regarding federal states with coefficients of minimum (maximum) as percentage of national average, the relative range, the maximum to minimum ratio, simple and weighted coefficients of variation, unweighted and weighted Gini indexes, Theil index, Hoover and Coulter coefficients. Hierro, Atienza, and Patiño (2007) use the relative range, the coefficient of variation, logarithmic variance, the concentration index, the Gini coefficient, the Reynolds-Smolensky index, the PechmanOkner index and the reranking contribution in 


\section{Articles}

order to measure inequalities in the distribution of resources before and after equalization at regional level in Germany, Australia, Canada, Spain and Switzerland.

The interpretation of the host of issues relating to inter-municipal fiscal disparities, which accompanies the process of decentralisation, does not have an extensive history in Bulgaria. To answer the question as to the effectiveness of the system applied in Bulgaria in order to alleviate inequalities at local level we use traditional instruments for measuring fiscal disparities among municipalities before and after equalization, including the ratio of maximum to minimum values of per capita own revenue, coefficient of minimum as percent of national average and coefficient of variation. To measure inequality, we explore Gini coefficients. The later are calculated as the ratio of the area between the Lorenz curve and the 45-degree line to total area under the 45-degree line. We also use Atckinson-Plotnick re-ranking index to capture re-ranking effects of the equalization transfers. In addition, we show
An Analysis of Equalizing Capacity of State Transfers

for Local Government Activities in Bulgaria

graphically Lorenz curves before and after the transfers.

\section{Bulgarian Local Government Revenue Profile}

The Bulgarian two-tier system of public sector comprises of the central government and 265 municipalities. Revenue assignment between levels of government in Bulgaria is a result of actions taken to clearly define the responsibilities of municipalities and identify the sources of their financing as part of efforts undertaken to reform local finance system during the years 2003 to 2007. Revenue accruing to local government budgets in Bulgaria could be divided into two broader groups - own revenue and intergovernmental transfers. Own revenue component includes local taxes, user fees and non-tax revenue. The second revenue group comprises the central government transfers to municipalities, which have three elements - a general transfer for delegated activities, a general equalization transfer for local activities and a conditional transfer for capital expenditure.

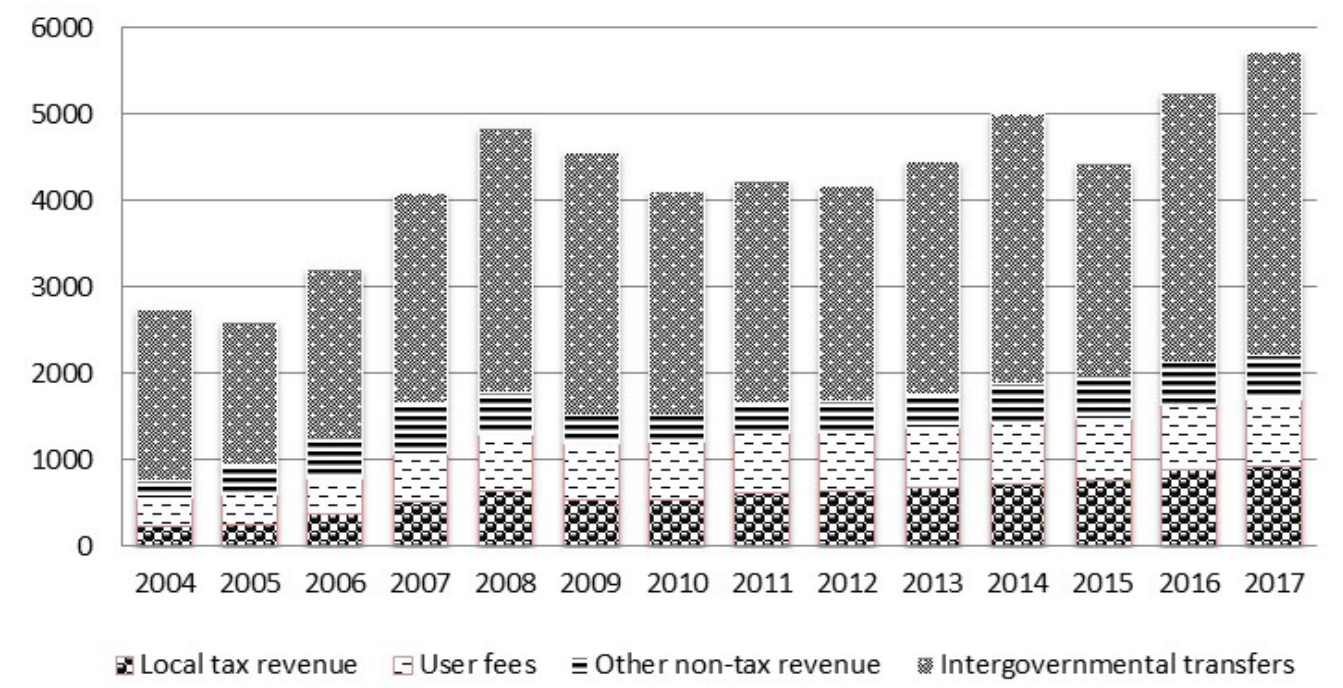

Figure. 1. Local government revenue structure for the period 2004-2017 (BGN millions)

Source: Ministry of Finance data on consolidated fiscal program (2004-2017), Annual Reports on State Budget Execution; own calculations 


\section{Articles}

Total municipal revenue has expanded significantly during the years in the pre-crisis period implying the increased importance of municipalities in the economy and the public sector in Bulgaria. (Fig. 1). Until 2008 municipal spending grew at a relatively high pace, with own municipal revenue registering a twofold increase. The higher local revenue base, as well as broadened revenue decision-making power of local governments in Bulgaria (as part of the Fiscal Decentralization Program launched in 2003) created conditions for own revenue increase, which reached a nominal peak in 2008 (Fig. 1). The largest own-source revenue for local governments in Bulgaria is the income generated through user fees. Together with other non-tax revenue they account for more than $60 \%$ of own revenue receipts. Since 2008 local governments have the power to set rates of local taxes within certain brackets set by the law. Local governments are not allowed to introduce taxes beyond those enumerated in the Law of local taxes and fees. All municipal revenue is collected by the municipal tax administrations and accrues into the budget of the municipality in which they were made, with local authorities exercising full control over their own source revenue. The growth of own revenue in the period 2004-2008 is followed by a serious decrease in its volume as a consequence of the crisis which coupled with the cut in the capital expenditure grant by almost $65 \%$ in 2010, had a strongly negative effect on municipal budgets during the consequent years.

During the period under review no changes in the structure of municipal revenue is observed. The main component of municipal revenue is the central government transfers with a share of approximately $60 \%$ of total revenue over the years, followed by non-tax revenue and income from local taxes, with the lowest share. The dominant share of central government transfers could be explained with the tax base centralisation with municipal tax revenue share in consolidated tax revenue reaching about 3\%. Potentially, this should have enabled central government to narrow significantly fiscal disparities at local level since the tax centralization gives central government more tax resources to perform fiscal equalization.

One of the main achievements of the process of decentralisation in Bulgaria was the comprehensive reform of the system of State transfers intended for the municipalities. The aim of the reform was to achieve a clear separation of public services delivery responsibilities between the central government and municipalities, on the one hand, while also achieving greater transparency and introducing clear rules in respect of the intended purpose and manner of allocating transfers to individual municipalities. The mechanism first introduced in 2003 for determining and allocating transfers was underlined by the separation of activities financed from municipal budgets into local and State-delegated. The latter are financed by the central government through a general transfer for delegated activities on the basis of approved spending standards Local activities, which are optional, are provided by municipalities, depending on demand, the needs of the local population and available financial resources. The provision of local activities is financed with the own municipal revenue and the general equalising transfer.

The general transfer for delegated activities is aimed at achieving national standards in delivering services like health, education and social welfare. Thus the funds transferred in this way are earmarked to the designated programs administered by the municipalities, acting essentially as agents of the central government. Central financing of delegated services through the general 


\section{Articles}

transfer is intended to cover only current expenses. The capital expenditure transfer, which also seeks to simultaneously attain other goals, is intended to finance capital spending part of delivering both delegated and local activities. The general equalization transfer for local activities represents the only form of intergovernmental transfers in Bulgaria explicitly designed to tackle fiscal disparities at local level, and to compensate for the different fiscal capacities and expenditure needs of municipalities.

\section{Evolution of Equalization System in Bulgaria}

The general equalization transfer (GET) is intended to ensure a minimum level of local service delivery in municipalities by supplementing their own revenue in the financing of local activities. The size of GET pool is determined by the law -it may not be less than $10 \%$ of the total reported own revenue of all municipalities for the previous year.
An Analysis of Equalizing Capacity of State Transfers

for Local Government Activities in Bulgaria

The fundamental criterion for evaluating an equalization transfer system is its equalizing effect on municipal fiscal disparities. The final equalizing effect will depend on both the relative importance of GET in municipal budgets and on the manner of its distribution. The first of these two aspects is captured in Table 1. The data set out in the table shows that the equalizing transfer has been growing in absolute terms and as a share of total State transfers. In 2010 the total amount of GET was reduced by about $10 \%$ compared to the previous year, and its size remained unchanged during the period 2011-2013 as a results of the central government budget cuts and attempts to create fiscal space to deal with the crisis At the same time, during the period under consideration the size of the total equalizing transfer struggled to exceed $10 \%$ of the total amount of State transfers, meaning that the central government was using only a tenth of all transfers in order to equalize the fiscal disparities between municipalities, despite the centralization of tax revenue and the large share of transfers in municipal budgets reaching up to $60 \%$.

Table 1. General equalization transfer (2007-2017)

\begin{tabular}{llllllllllll}
\hline & $\mathbf{2 0 0 7}$ & $\mathbf{2 0 0 8}$ & $\mathbf{2 0 0 9}$ & $\mathbf{2 0 1 0}$ & $\mathbf{2 0 1 1}$ & $\mathbf{2 0 1 2}$ & $\mathbf{2 0 1 3}$ & $\mathbf{2 0 1 4}$ & $\mathbf{2 0 1 5}$ & $\mathbf{2 0 1 6}$ & $\mathbf{2 0 1 7}$ \\
\hline $\begin{array}{l}\text { GET } \\
\text { (in BGN mIn) }\end{array}$ & 103.5 & 173.4 & 241.8 & 217.7 & 241 & 241 & 241 & 255.6 & 264 & 297 & 304 \\
$\begin{array}{l}\text { GET in \% } \\
\text { of total transfers }\end{array}$ & 4.2 & 5.6 & 8.0 & 8.4 & 9.5 & 10.1 & 10.4 & 10.5 & 10.3 & 10.1 & 10.5 \\
\hline
\end{tabular}

Source: Ministry of Finance data on consolidated fiscal program (2007-2017), Annual Reports on State Budget Execution; own calculations

Initially, GET provision was targeted at addressing disparities in local tax base or fiscal capacity of local authorities in Bulgaria, i.e. the transfer was provided to municipalities with tax revenue per capita below the national per capital average. Its aim was to reduce the differences in tax revenues across municipalities, which was done by giving more resources to those municipalities with lower per capita tax revenues and excluding from benefits those municipalities for which this variable was higher than the national average. In fact, GET formula design suggests that the equalization mechanism equalized implemented or actual revenue from local taxes and not the potential tax capacity of local governments. 


\section{Articles}

The main argument for equalizing municipal tax capacity only was that until 2008 local authorities in Bulgaria did not have tax autonomy, i.e. they could not in any way influence the amount of revenue from local taxes. To the extent that most municipalities in Bulgaria had tax revenue per capita around or lower than the national average and very few had high revenue from local taxes per capita, the number of municipalities that did not have access to equalizing transfers was very small. The equalization of tax revenue per capita up to the national average has not been achieved in full and has varied over the years.

In 2007, the transfer distribution formula included a second element, in an attempt to address the differences in expenditure needs, i.e. it equalized both local government revenue and expenditure. The amount of the equalizing transfer per municipality in 2007 was calculated on the basis of the following formula: $C_{2}=A_{1}+A_{2}$

The $A_{1}$ component of the transfer was payable to municipalities with below average revenue from local taxes per capita, with equalizing coefficient up to $90 \%$ of the difference between the national average and the tax revenue per capita of the respective municipality. Access to the $A_{2}$ component of the transfer was available to municipalities with current expenditure for local activities per resident (excluding salaries, social insurance contributions and cleaning activities) that was lower than $110 \%$ of the national average per capita. The criteria for allocation of this component of the transfers, which applied only to the municipalities with access to the component in question, were as follows: a) territory in sq.km. with a weight of $40 \%$; (b) number of children up to the age of 5 years with a weight of $30 \%$; c) number of senior citizens above the age of 65 years with a weight of $30 \%$. The distribution of the respective amounts between the municipalities with access on the basis of the three criteria depended on the relative share of each criterion of the total. The last year during which some municipalities were ineligible for the transfer was 2007. This was also the last year in which the transfer calculation formula did not contain any other elements, except revenue and spending equalization.

Since 2008 cost equalisation aimed at reducing differences in the per capita cost due to higher unit cost of two particular services. The spending needs of municipalities were taken into account on the basis of standards for two types of services - establishments for children and mobile home visitation services. According to these standards the maintenance cost per child per establishment was BGN 403 and the scope of coverage for the purpose of service financing was $43 \%$ of children up to the age of 5 years living in the territory of the respective municipality. According to the standard for mobile house visitation services the cost of service delivery was BGN 559 and the coverage of the service was $3 \%$ of elderly people aged 65 years and above living in the territory of the respective municipality. Full access (100\%) to this component of the transfer was available to the municipalities with current expenditure for local activities per capita (excluding salaries, social insurance contributions and cleaning activities) that was lower than the national average, while the access of all other municipalities was capped at $50 \%$. In addition to equalizing the revenue capacity and spending needs of municipalities in 2008 two new elements were added to the formula. The $\mathrm{A}_{3}$ component took into account the forecast inflation for 2008 and the $\mathrm{A}_{4}$ component compensated the negative difference between the estimated revenue from the newly introduced patent tax and the compensation for the revenue from the repealed road tax. 


\section{Articles}

During 2010, only the $A_{3}$ component remained in the formula, its aim being to ensure that during the respective year each municipality receives at least the amount of the transfer it received in the previous year. Full access (100 \%) to this transfer was available to the municipalities with a negative difference and tax capacity per capita lower than the national average. The remaining municipalities with a negative difference and a higher than average tax capacity had limited access capped at 89.7 percent.

A significant change in the method of allocation of the transfer was introduced in 2011. At the time, tax capacity equalization began to take into account the tax effort of a given municipality. It was measured as the average ratio between property tax rates and the property acquisition (by a remunerative transaction) tax rate set by the municipal council in the respective municipality and the maximum rates stipulated by law. The closer the tax effort of the respective municipality to the maximum rate (expressed as 1), the higher the share of the equalizing transfer under the component paid to be municipality. And vice versa - the share of the transfer under this component of the equalizing subsidy was reduced where municipalities do not levy the maximum rate stipulated by law. Although this reduction was insignificant, it attempted to ensure a more equitable allocation of the funds. Together with the equalization of the tax capacity and spending needs, the additional $A_{3}$ component continued to be used. The
An Analysis of Equalizing Capacity of State Transfers

for Local Government Activities in Bulgaria

formula was yet again changed in 2015 to include an additional component $A_{4}$ access to which was available only to municipalities with own revenue below $20 \%$ of their total expenditure. Since 2016, the additional $A_{4}$ component has been allocated solely to those municipalities in which the property tax collection rate is above the national average.

The review of the equalizing transfer formula design over the years shows that major differences can be found in 2007 and 2011 equalization mechanisms. Insofar as 2017 is the last year for which data is available, the next section of this paper sets out a comparative analysis of the effect of the funds allocation mechanism applied on intramunicipal financial disparities during the three years in question.

\section{The disparity-reducing effect of fiscal equalization in Bulgaria}

Identifying the disparity-reducing effect of transfers for local activities in Bulgaria requires performing two-stage analysis. First, in order to evaluate the original inequality for the three years chosen - 2007, 2011 and 2017, we estimate the existing disparities in per capita own revenue among local governments in Bulgaria. The equalizing effects of the three transfer mechanisms are then captured comparing the values in these statistics before and after receiving GET. Lower values after transfers would proof the effectiveness of general equalizing grant to reduce disparities in municipal own revenue.

Table 2 Inequality statistics for 2007, 2011 and 2017

$\begin{array}{llll}\text { Pre-transfer inequality } & & & \mathbf{2 0 1 1} \\ \text { Max } & \mathbf{2 0 0 7} & \mathbf{2 0 1 7} & 4973.59 \\ \text { Min } & 1892.95 & 2946.56 & 82.95 \\ \text { Max/Min } & 23.45 & 39.75 & 59.95 \\ \text { Average } & 80.72 & 74,12 & 285.54 \\ \text { Min/Average (in \%) } & 178.86 & 194.79 & 29 \% \\ \text { Co of Var } & 13 \% & 20.4 \% & 1.34 \\ \text { Gini coefficient } & 1.50 & 1.34 & 0.36\end{array}$




\section{Articles}

\begin{tabular}{llll} 
After transfer inequality & & & \\
Max & $\mathbf{2 0 0 7}$ & $\mathbf{2 0 1 1}$ & $\mathbf{2 0 1 7}$ \\
Min & 1893 & 2976.02 & 5011.63 \\
Max/Min & 52 & 101.12 & 165.90 \\
Average & 36.40 & 29.43 & 30.20 \\
Min/Average (in \%) & 201.90 & 249.45 & 352.13 \\
Co of Var & $25 \%$ & $40 \%$ & $47 \%$ \\
Gini coefficient & 1.30 & 1.02 & 1.06 \\
Equalizing effect & 0.43 & 0.30 & 0.28 \\
(Gini before - Gini after) & 0.08 & 0.10 & 0.08 \\
$\begin{array}{l}\text { Re-ranking index } \\
\text { (Gini after-Ci) }\end{array}$ & $-0,0011$ & $-0,0096$ & $-0,0057$ \\
Reranking contribution & & & \\
R/( Gini before - Gini after) & 0.014 & 0.096 & 0.071 \\
\hline
\end{tabular}

Source: Own calculations based on NAMRB internet platform for local finance. http://www.namrb.obuchi-se.org/norway/bg-bg.aspx

We start the analysis with the distribution of own revenue among municipalities before GET distribution. The distributions of per capita own revenue among local governments is similar during the period under review (Appendix1). The share of municipalities with per capita own revenue exceeding the national average barely reaches $15 \%$, the wealthiest local governments are few and the level of their per capita revenue sharply contrasts to that one of the remaining multitude. The value of the relative range in 2007 is 10.45 which means that the difference between per capita resources obtained by the wealthiest municipality and the municipality with the lowest own revenue per person is 10.45 times the mean. During the years this gap has widen to 14.92 and 17.12 in 2011 and 2017 respectively since the distance between the wealthiest municipalities and the country average in per capita terms has increased significantly as a result of tax revenue mobilization efforts and growing concentration of economic activity in few urban economic centers.

The nature of local government ownsource revenue distribution in Bulgaria is further explored in Table 2, which presents descriptive statistics for per capita own revenue in 2007, 2011 and 2017. The statistics in this table suggests that there is substantial variation in revenue collections across local governments. In 2007 in per capita terms, the wealthiest municipality generates 80 times more own source revenue per person than the most poorly one and the coefficient of variation may be considered as rather high at 1.50. In 2011 u 2017 the values of maximum/ minimum coefficient are respectively 74 and 60 . According to the coefficient of variation and Gini coefficient we can also see that the original inequality in the per capita own revenue is larger in 2007 than in 2011 and 2017. However, the analysis of the evolution of the coefficient of variation suggests that during the period 2011-2017 municipal disparities tend to be persistent.

After the distribution of GET a higher inequality is reported in 2007 as all the indicators show. In fact, the inequality degree after GET in 2007 - 43\% approximately equals the 2011 pre-transfer inequality. The values of Gini indexes in 2011 and 2017 are respectively $30 \%$ and 27\%. In Figure 2 and Figure 3, which represents Lorenz curves before and after transfers we can distinguish two effects. First, there is a reduction in financial disparities among municipalities after the distribution of equalization grant in all three years. And 


\section{Articles}

second, the resulting inequality after the application of 2011's and 2017's equalization systems is almost identical.

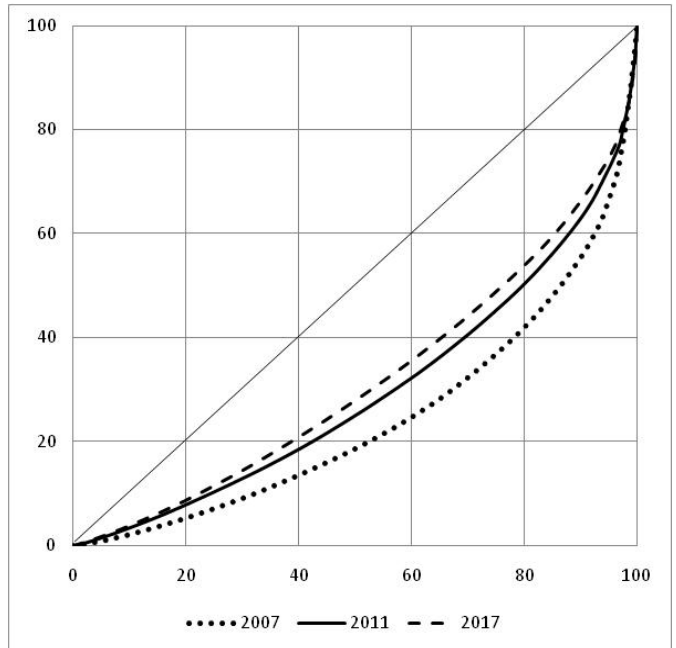

Figure 2. Lorenz curves before distribution of GET

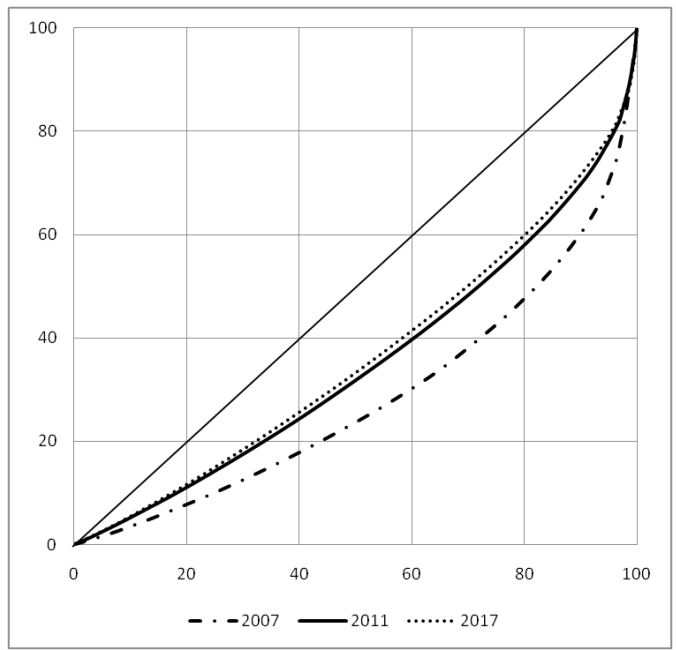

Figure 3. Lorenz curves after distribution of GET Source: Author

The disparity-reducing strength of GET system is measured with its equalizing effect, defined as a difference between Gini coefficients of pre-transfer local government per capita own revenue income (Gbefore) and post- transfer local government per capita income (Gafter). The equalizing effect of the three equalization schemes is measured with
An Analysis of Equalizing Capacity of State Transfers

for Local Government Activities in Bulgaria

the fall in Gini coefficients values, presented in Table 2. The comparison of values of Gini indexes before and after transfers shows that the 2011's equalization system produces the highest inequality decrease of $10 \%$. The 2007's and 2017's equalization systems decrease the inequality with about 8 points respectively.

To sum up, we can conclude that all the three equalization mechanisms produce a decrease in inequality in the initial distribution of municipal own-source revenue. However, the size of the equalizing effect remained almost constant between 2007 and 2017, with no significant improvement despite the fact that GET distribution formula experienced numerical changes during the years. It should be mentioned that the equalizing effects of transfers in 2011 and 2017 is with a stronger impact on the municipalities with lowest per capita own revenue. In this way the reduction of the distance between the minimum to the average value after the transfer is higher in 2011 and 2017 as compared to 2007. At the same time, the remaining disparities among local governments in Bulgaria are still considerable which implies that the equalizing effects are rather mild. For comparison, a study of OECD (Blöchliger and Charbit, 2008) shows that on average (the coefficients of variations and Gini coefficients produce the same results) fiscal disparities decreased by two thirds or approximately by $70 \%$, and in some countries the equalization system almost eliminated the pre-transfer disparities, making after-transfer Gini coefficient equal to 0 .

Yet another effect of the equalization transfers in Bulgaria to be captured is reranking, which is a common feature of any grant system. It is expected that an equalization transfer would move the Lorenz curve toward the line of equality thus narrowing the distance between local government own revenue and their total income (own revenue plus transfer) 


\section{Articles}

after the equalization. Despite the fact that a transfer system may be equalizing, it could lose its impact to some extent since during the equalizing process the original ranking of local governments according to their per capita own revenue could be altered. As a result of re-rankings some local governments that originally had lower levels of own revenue could gain relatively more transfers than others and after the equalization could change their positions and get higher in the post-transfer ranking in comparison with other local governments who had originally higher per capita own revenue. Since 'when evaluating the overall impact of taxes and transfers on inequality, one might well care about whether inequality reductions result from reranking or from gap-narrowing' (Lerman and Yitzhaki, 1995, p.2) we will calculate the re-ranking contribution to the overall redistributive effect of equalization transfers in Bulgaria.

The extent of re-ranking can be measured by using the Atkinson-Plotnick re-ranking index (Creedy, p.27). The negative sign before the index only reflects the fact that re-ranking could alter the equalizing effect of the transfer and could violate equity. The re-ranking index - $\mathrm{R}$ equals the difference between Gini inequality measure after the transfer (Gafter) and the concentration index $(\mathrm{Ci})$ - a measure derived from concentration curve. The later is similar to Lorenz curve, but it expresses the total revenues (own plus transfers) of local governments based on their initial ranking the one before the distribution of transfers. Dividing $\mathrm{R}$ to the difference between the pretransfer and after-transfer Gini coefficients will result to a single index measure which will indicate about the re-ranking contribution to the equalization process. It is considered that values above 0.5 of this composite index generate significant losses in equity (Plotnick, 1981).
We can see from the data in Table 2 that each one of the three transfer systems changes the position of some local governments in income distribution and that 2011's grant system stands out in this respect. It is obvious that much smaller re-ranking effects in 2007 which amounts to $1.41 \%$ of the equalizing effect only partially offset the redistribution towards the poor local governments. Although all of the three transfers systems affect the position of local governments they do not produce high losses of grant's equalizing power. Re-ranking amounts to $9.6 \%$ of the transfers' equalizing effect in 2011 and to $7.1 \%$ of the equalizing effect in 2017 respectively.

\section{Conclusion}

First introduced in 2003, the changes in the Bulgarian local government finance system have resulted in the implementation of a new approach aiming at equalizing existing intramunicipal financial disparities. Initially, the formula allocated the funds from the general transfer for local activities in order to equalize only the revenue capacity of municipalities, i.e. supplement the own revenue from local taxes for municipalities in which the revenue from local taxes per capita was lower than the national average. Since 2007 some of the funds made available for local activities have been determined on the basis of indicators that take into account the spending needs of local governments. A feature of the equalization mechanism applied in subsequent years was the inclusion of a number of additional elements in the distribution formula and the greater complexity of access requirements.

The analysis conducted shows a wide variation in Bulgarian local government per capita own revenue. General equalization transfers diminish total variation in fiscal outcomes while comparing the extent of inequality before and after equalization. However, the remaining fiscal disparities 


\section{Articles}

after the equalization are still sizable. The equalizing effect of transfers has remained virtually unaltered during the past decade despite of the numerous changes that the equalization mechanism has undergone.

One of the reasons for the equality strength of GET remaining almost equal during the years 2007 through 2017 is the constant addition of different compensatory elements in the distribution formula, which cannot be linked to the equalization of either revenue or spending. These elements are geared toward different types of compensation and together with the access system applied have been acting as a tool for allocation of funds from GET in manual mode, transforming it from an equalization mechanism into one that to a great extent supplements the revenues and spending of municipalities. Although State transfers have a prevalent share in municipal revenue during the period under review it was not able to increase the equalizing strength of transfers for local activities. It is also possible to explain the resulting equalizing effect of GET with its small relative share in the total amount of transfers - approximately 8 to $10 \%$ over the years. However, there is still potential to reduce disparities among local governments by distributing centralized tax recourses via intergovernmental transfers or trough tax sharing.

\section{References}

Annual State Budget Acts of Republic of Bulgaria, Appendix 5 Mechanism for Determining and Allocating the Transfers for Municipalities in Bulgaria. State gazette 108/29.12.2006; 113/28.12.2007; 110/30.12.2008; 99/15.12.2009; 99/17.12.2010; 99/16.12.2011;102/21.12.2012; 109.20.12/2013; 107/24.12.2014; 96/09.12.2015; 98/09.12.2016 Bird R., Tarasov A.V., 2004. Closing the Gap: Fiscal imbalances and intergovernmental transfers in developed federations. Environment and Planning $C$ :
An Analysis of Equalizing Capacity of State Transfers

for Local Government Activities in Bulgaria

Government and Policy, 22(1), 77-102. https:// doi.org/10.1068/c0328

Blöchliger, H., Charbit,C.,2008. Fiscal equalisation, OECD Journal: Economic Studies, vol. 2008/1. https://www.oecd.org/ eco/42506135.pdf

Boadway, R.,2004. The Theory and Practice of Equalization, CESifo Economic Studies, Volume 50, Issue 1, 2004, Pages 211-254. https://doi.org/10.1093/cesifo/50.1.211

Cowell F.A., 2011.Measuring inequality, 3rd ed., LSE Perspectives in Economic Analysis, Oxford University Press, New York

Creedy, J., 2001. Taxation and Economic Behaviour: Introductory surveys in economics (Vol. 1). Cheltenham,UK॰North ampton,MA,USA:Edward Elgar Publishing.

Hierro, Luis A., Atienza.P., Patiño, D., 2007. Inequality and Progressiveness in the Distribution of Revenues of the States in Federal Countries: A Comparitive Study, International Center for Public Policy Working Paper Series, at AYSPS, GSU paper0703, International Center for Public Policy, Andrew Young School of Policy Studies, Georgia State University. https:// icepp.gsu.edu/files/2015/03/ispwp0703.pdf

Hofman, B. and Cordeira Guerra, S. 2005. Fiscal Disparities in East Asia: How Large and Do They Matter?, East Asia Decentralizes: Making Local Government Work, Washington, DC: The World Bank. http:// siteresources.worldbank.org/INTEAPDECEN/ Resources/dc-full-report.pdf

IME, 2018.Regional Profiles. [Online] Available at: https://www.regionalprofiles.bg/ var/Economic-Centres-BG-2018.pdf (accessed 20 December 2018).

Kowalik,P., 2015. Horizontal Fiscal Imbalance in Germany. Business and Economic Horizons, Volume 11, Issue 1, pp.1-13. http://dx.doi.org/10.15208/ beh.2015.01

Martinez-Vazquez,J., Timofeev,A., 2006. Regional-Local Dimension of Russia's Fiscal Equalization. International Center for Public 


\section{Articles}

Policy Working Paper Series, at AYSPS, GSU paper 0616, International Center for Public Policy, Andrew Young School of Policy Studies, Georgia State University. https:// icepp.gsu.edu/files/2015/03/ispwp0616.pdf

Lerman, R. I., Yitzhaki, S., 1995, Changing ranks and the inequality impacts of taxes and transfers, National Tax Journal, 48(1), 45-59.

Martinez-Vazquez,J., Sepúlveda,C., 2008. The Municipal Transfer System in Nicaragua: Evaluation and Proposals for Reform. International Center for Public Policy Working Paper Series, at AYSPS, GSU paper 0801, International Center for Public Policy, Andrew Young School of Policy Studies, Georgia State University.

https://icepp.gsu.edu/files/2015/03/ ispwp0801.pdf

Ministry of finance of Republic of Bulgaria, Data on consolidated fiscal program (20042017). [Online] Available at: http://www. minfin.bg/bg/statistics/13 (accessed 20 December 2018).

Ministry of finance of Republic of Bulgaria, Reports on Implementation of the State Budget 2004-2017. [Online] Available at: http://www.minfin.bg/bg/247 (accessed 20 December 2018).

Muñoz, A.F., Radics,G.A., Bone,C., 2016. Subnational Fiscal Disparities and Intergovermental Transfers in LAC. Hacienda Pública Española, IEF, vol. 219(4), pp. 35-66, December.

http://www.ief.es/docs/destacados/ publicaciones/revistas/hpe/219_Art2.pdf

National Association of Municipalities in Republic of Bulgaria, An internet platform for local finance. [Online] Available at: http://www.namrb.obuchi-se.org/norway/ bg-bg.aspx (accessed 20 December 2018).

Oates,W.,1972. Fiscal Federalism, New York:Harcourt Brace Jovanovich.

OECD, 2014. Fiscal Federalism 2014: Making Decentralisation Work, OECD Publishing, Paris. https://doi.org/10.1787/9789264204577-en
Plotnick,R., 1981. A Measure of Horizontal Inequity. The Review of Economic and Statistics, Volume 63, Issue 2, pp.283-288.

Portnov B.A., Felsenstein D., 2010. On the suitability of income inequality measures for regional analysis: Some evidence from simulation analysis and bootstrapping tests, Socio-Economic Planning Sciences, Vol.44(4), pp.212-219

http://citeseerx.ist.psu.edu/viewdoc/download ?doi=10.1.1.707.9521\&rep=rep1\&type=pdf

Primorac,M., 2015. The effectiveness of fiscal equalisation in Croatia. Economic ResearchEkonomska Istraživanja, 28:1, pp.299-311. https://hrcak.srce.hr/171515?lang=en

Primorac,M.,2914. The Restructuring of the Fiscal Equalization System in Croatia. Proceedings of Rijeka Faculty of Economics, Journal of Economics and Business, Vol. 32, No. 2, 2014, pp. 213-232 . https://hrcak.srce. $\mathrm{hr} / 131532$

Shneider,M.,2002. Local Fiscal Equalisation Based on Fiscal Capacity: The Case of Austria. Fiscal Studies, 23(1), pp.105-133. http://www.jstor.org/stable/24438338

Shah,A., 2007. A Practitioner's Guide to Intergovernmental Fiscal Transfers, in Robin Boadway and Anwar Shah (eds) Intergovernmental Fiscal Transfers. Washington,DC: World Bank.

http://siteresources.worldbank.org/PSGLP/ Resources/IntergovernmentalFiscalTransfers. pdf

Shankar R., Shah A., 2003. Bridging the economic divide within countries: A scorecard on the performance of regional policies in reducing regional income disparities, World Development Vol.31, No.8, pp.1421-1441

http://siteresources.worldbank.org/PSGLP/ Resources/Bridgingtheeconmicdividewithin $\mathrm{Na}$ tionsShankarShah.pdf

Tiebout C.M.,1956. A pure theory of local expenditures. The Journal of Political Economy, 64, pp.416-424. 
Appendix 1. Municipal own revenue per capita (in BGN thousand)
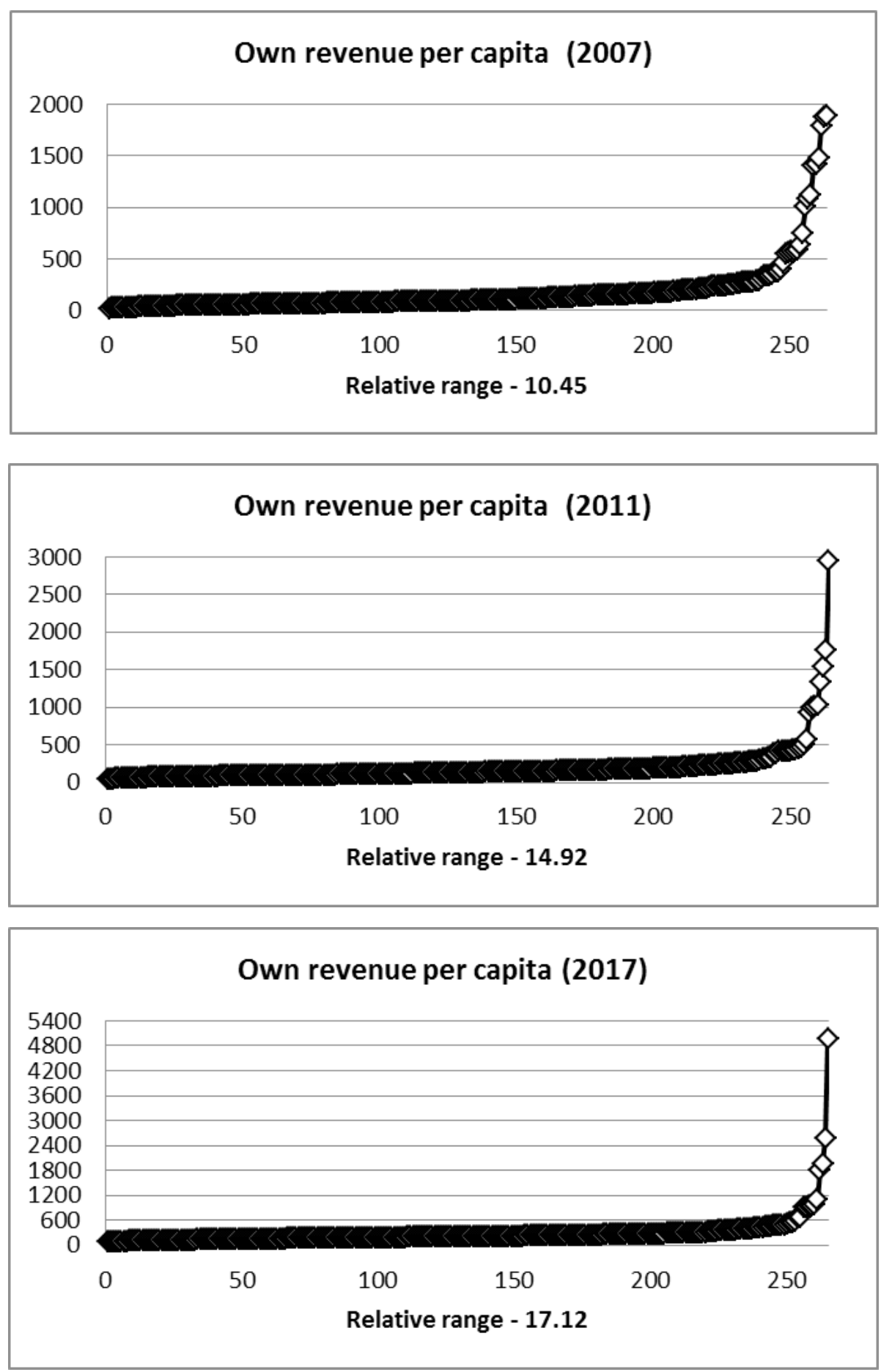